\title{
The Exploration of Cruise Tourism Development in the Silver Market
}

\author{
Huifen Zhou ${ }^{1} \&$ Jianyong Shi $^{1}$ \\ ${ }^{1}$ Shanghai University of Engineering Science, Shanghai, China \\ Correspondence: Huifen Zhou, Shanghai International Cruise Center for Economic Research, Shanghai University of \\ Engineering Science, Shanghai, China. E-mail: huifenzhou@126.com
}

Received: November 6, 2013

Accepted: November 16, 2013

Online Published: November 20, 2013

doi:10.5430/bmr.v2n4p56

URL: http://dx.doi.org/10.5430/bmr.v2n4p56

\begin{abstract}
It is the ocean tourism year in 2013 , in the point of the industry, the cruise tourism that grow fast in later years will become the most popular tourist theme in 2013. In recent years, with the rapid development of China's economy, the cruise focus gradually shift to east region, especially the potential of China's market is huge. With the support of market segmentation theory, this article through to the market both at home and abroad, summarize the characteristics of the elderly consumer market in China, analyzed the feasibility of the development of cruise tourism in silver market, and for the problems we faced during the development of cruise tourism, this article put forward to the suggestion from three aspects: the government, the cruise company and travel agencies.
\end{abstract}

Keywords: The cruise, The silver market, The market characteristics

\section{Introduction}

China tourism theme in 2013 identified as "2013 China ocean tourism year", and make "experience with the ocean, visit to China", "Marine tourism, leading the future", "ocean tourism, brilliant" as the slogan to promote outward. According to the Chinese transportation association cruise yacht club (CCYIA) statistics, in 2011, China received 262 international cruise ships, with growing by $17.5 \%$ year-on-year, had received 504582 cruise tourists from home and abroad. To develop Chinese cruise tourism, we must do in-depth research for China's potential market, understand the purchasing behavior and characteristics of Chinese tourists, so as to provide targeted cruise products adapt to Chinese consumers, promote the development of cruise tourism market in China.

Based on the overall grasp of the Chinese market, according to age, we can divide potential visitors into three parts: the silver market, the honeymoon market and home market. Silver market is elderly aged over 60 years old, they retired at home and have plenty of leisure time, is one of the greatest potential consumer groups to the development of cruise tourism. Here, we will discuss the feasibility of the silver market development and the analysis of the necessity is discussed.

\section{The Feasibility Analysis of the Development of Silver Market}

Tourism market must meet the following three elements: population, tourism purchasing power and desire. The market cannot be established without any of them. And the characteristics of the elderly tourism market can be summarized as: the people, the money and the desire. Older people have large potential to tourism. For older people in China, along with the development of social economy and the improvement of olders' living standard, their life and health index is used to have greatly improved. The rapid growth of aging population and their income, also with the improvement of the social welfare suggest that The elderly tourism market has entered the rapid growth stage. The silver market in the North America market show great vitality, so at the beginning of the cruise tourism development in our country, we should analyze the possibility of the development of Chinese elderly market in cruise tourism.

\subsection{Convenient}

The old man in the travel cannot be too tired, Cruise tourism is different from team tour type of tourism, its center is fixed in one place. In the port of call shore excursions activity is voluntary. This way, first of all, to ensure the comfort of holidays; Second cruise is a kind of luxury travel way, five-star service facilities, for the elderly care more convenient; In addition, on the cruise to watch the beautiful sea scenery is also another kind of enjoyment. 


\subsection{Plenty time}

For the retired old people, travel time is very abundant. Without time limit, they can do what they want to do that when they were young there was not a plenty of time and opportunity to do. And now most of the children has his own work, cannot be along with their parents, the old people also need not worry about daily trifles, so they can travel with their friends to live a more colorful life.

\subsection{Enough money}

According to the country about 2013 increases the overall requirements of enterprise retiree pensions, from January 1 , 2013 in Shanghai, for enterprise retiree who has been deal with emeritus formalities before the end of 2012, and get basic old-age pension by the month, and for people who get old-age pension by the month according to the "town", "city ju bao", "new farming keeps" to increase the pension. The increase of pension and the loss of stress in life made older-market very $\mathrm{p}$ has huge consumption potential. Compared with the young and middle-aged, most old people have responsibility neither to support their parents nor to raise children. Thus it meet their own needs as they want, and they will be translate limited economic income maximize into realistic purchasing power, the marginal propensity to consume is significantly higher than middle-aged and young consumers.

\subsection{The elderly population size is big}

Now in China is a populous country, with the aging process, part of the aging population has accounted for a relatively large proportion, the scale is very large, and the life of old people also showed a trend of rising. According to the date from National Bureau Statistics, China's average life expectancy has reached 74.83 years of age, The prolongation of the service life of the development potential of the silver market is huge. Shanghai is the city with the highest population aging city. In 2012 the city's population of 60 years old of 3673200 people, accounting for $25.7 \%$ of the city population. Is expected by the end of 2015 , the ratio of close to $30 \%$.
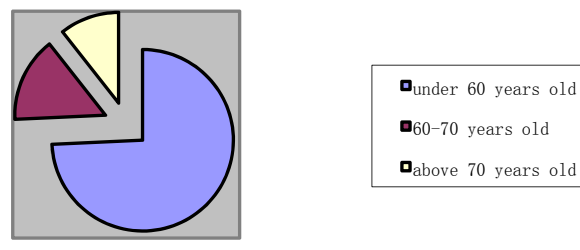

Chart 1. The population of 60 years old in Shanghai in 2012

Data sources: Shanghai Municipal Bureau of Statistics

Table 1. The basic situation of Shanghai elderly population survey

\begin{tabular}{l|l|l}
\hline Categories & number & Rate (\%) \\
\hline totals & 2248 & 100 \\
By age & & \\
$\quad$ 60-69 years older & 1320 & 58.7 \\
$\quad$ Above 70 years old & 928 & 41.3 \\
By monthly income & & \\
$\quad$ Under 2000 yuan & 864 & 38.4 \\
2000-3000 yuan & 923 & 41.1 \\
above3000 yuan & 461 & 20.5 \\
By health & 1300 & \\
$\quad$ Very well & 856 & 57.8 \\
$\quad$ health & 92 & 38.1 \\
sick & 1458 & 4.1 \\
By Household register & 790 & 64.9 \\
$\quad$ city & 35.1 \\
$\quad$ rural &
\end{tabular}

Data sources: Shanghai Municipal Bureau of Statistics 


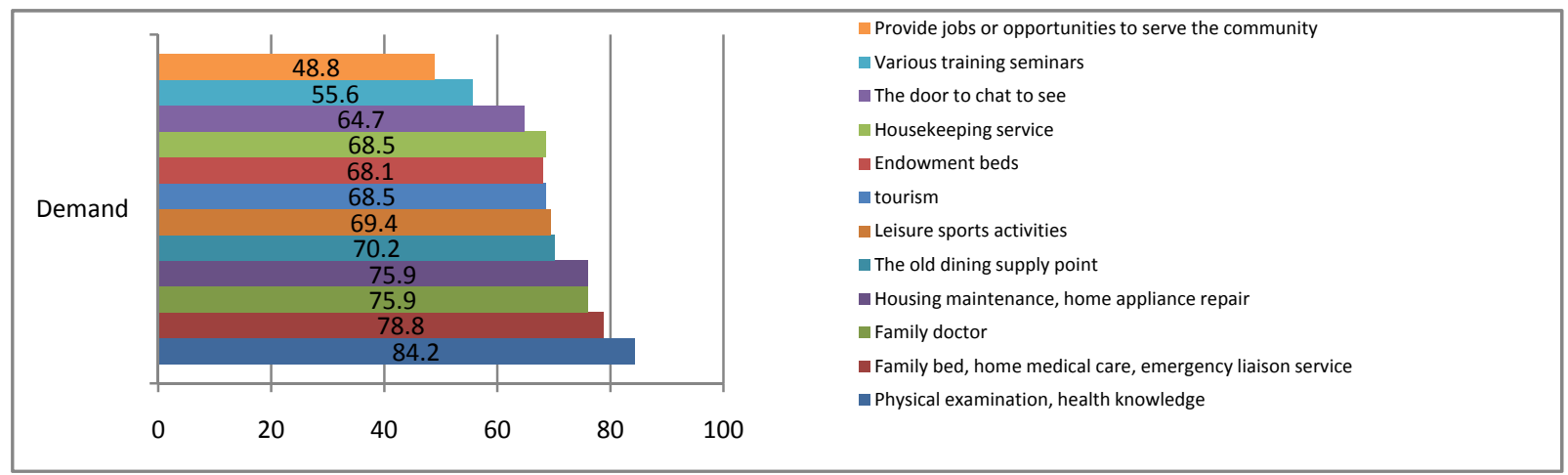

Chart 2. Shanghai elderly population in community services demand

Data sources: Shanghai Municipal Bureau of Statistics

According to the survey, more than $68 \%$ of the elderly have demand for sunset red tourism activities. With the aging of the population is becoming more and more serious, the community of retired old people has increased year by year, log "young" man body is hale and hearty, retired and have more spare time, more suitable for travel.

\subsection{The tourism consciousness has largely improved}

Modern people pay attention to the quality of life, especially on leisure tourism. In the last two years, the number of outbound tourism is constantly increasing. Now most of the elderly is relatively poor in material and spiritual life spend their youth, have no chance to meet the leisure tourism that the pursuit of a higher level of life. On the other hand, when they are freed from busy work and family burden, will burst into strong compensation requirements and hope that his later life can have a happy, fulfilling and colorful life.

\section{The problems existing in the silver market development}

\subsection{Warroied about the Security of cruise tourism}

The Titanic as familiar, although we all marveled by the magnificent cruise and poignant love story, but he met reefs and wrecks, things that resulted in the deaths of a large number of tourists also in people's mind, as a result, a lot of people pay attention to the safety of the elderly, in particular, are afraid of what will happen that cruise this sinking, therefore, impression of cruise has both desire and fear.

\subsection{Older may suffer from healthy question}

As the improvement of modern social medical treatment, the health of the elderly population has had the very big improvement. The elderly over the age of 50 is mature generation now. But there are many older elderly people because of work when he was young, with poor physical health, their children are very worried when they going out of their own.

\subsection{Some interpersonal factors}

Some old people, especially the single, because of the children have to work, there be no one to accompany to travel. Cruising the new way of tourism, especially like to flying over the sea by boat tour, in a big ship is lonely.

\subsection{They cannot adapt to the Culture and language}

There are a lot of foreign servers on the cruise; their Chinese level is not very good. Chinese tourists, especially the elderly tourists' English level is low, will cause the communication barriers. And the different culture cause different habits. In west countries, thirteen is an unlucky number, so a lot of foreigners will avoid using 13 or some Numbers, associated with 13 and 4 in China is relatively bad Numbers we will as far as possible avoid the use of the number4. The cultural differences and so on some other will be a big part of the old man of tourists make it difficult to adapt to this is different from the traditional domestic culture abroad. 


\section{Suggestions for the development of cruise tourism in Silver Market}

\begin{tabular}{|c|c|c|c|c|c|}
\hline \multirow{2}{*}{\multicolumn{3}{|c|}{ Stimulate consumer }} & \multirow{3}{*}{ motivation } & \multicolumn{2}{|c|}{ 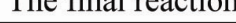 } \\
\hline & & & & 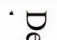 & when \\
\hline \multirow{2}{*}{$\begin{array}{c}\text { Internal } \\
\text { stimuli }\end{array}$} & \multirow{2}{*}{$\begin{array}{l}\text { External } \\
\text { stimulus }\end{array}$} & \multirow[t]{2}{*}{ Other } & & : & \multirow{4}{*}{$\begin{array}{l}\text { who } \\
\text { how many } \\
\text { products } \\
\text { price }\end{array}$} \\
\hline & & & \multirow{2}{*}{$\begin{array}{l}\text { Consumer } \\
\text { characteristics }\end{array}$} & \multirow{3}{*}{ 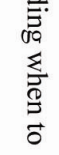 } & \\
\hline \multirow{3}{*}{$\begin{array}{l}\text { Physiology } \\
\text { Psychology }\end{array}$} & \multirow{3}{*}{$\begin{array}{l}\text { Marketing } \\
\text { Promotion }\end{array}$} & \multirow{3}{*}{$\begin{array}{c}\text { economic } \\
\text { culture } \\
\text { society }\end{array}$} & & & \\
\hline & & & $\begin{array}{l}\text { Purchase decision- } \\
\text { making process }\end{array}$ & & \\
\hline & & & & \multicolumn{2}{|c|}{ reject } \\
\hline
\end{tabular}

Chart 2. The basic behavior of buying behavior

There are a lot of factors that can stimulate the consumers buying products, for example, the internal factors and external factors. External factors attracting policy product, apply the marketing strategy and social factors, the promotion, will enable consumers to produce the impulse of consumption. Therefore, the cruise company design of cruise and cruise route etc. products, travel agency publicity marketing strategies and the role of government support policies, development of Chinese cruise tourism market is very meaningful. Therefore, this paper analysis the strategies that help develop the silver market from the three aspects. Model is shown in figure 1.

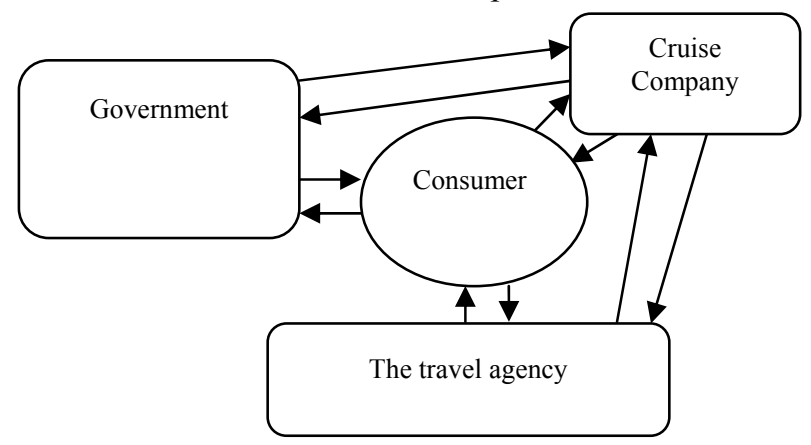

Figure 2. silver marketing pattern

\subsection{Cruise Company}

To strengthen the cooperation with travel agencies, especially the more large travel agency, because the elderly are more believe credibility higher travel agencies. According to the consumption characteristics of old people, they are careful, pay much attention to the product cost performance, especially the disposable products high cost. Therefore, more attention should be paid to the establishment of the cruise company reputation in the Chinese market.

In addition, the cruise company should hold the tourism festival and other tourist publicity activities to improve the knowledge of cruise tourism. Now people awareness of the cruise also limited the luxurious appearance and facilities, and can reach another tourist destination, the understanding of the liner is in itself a destination is not enough, so people feel very strange for the cruise. Cruise culture did not spread, therefore, the company should expand the influence of the cruise, as far as possible to make people familiar with the cruise ship, and understand him. In tourism festival, for example, big travel agency show cruise models to potential tourists or cruise products as well as the current route to strengthen people's understanding about cruise tourism.

According to the characteristics of the Chinese people, the cruise company should be appropriate to develop some short but high quality experiential cruises. Before people to experience, according to have learned that some information, psychological will have certain expectations, if the experience short of psychological expectations, they will rejected this new way of tourism, and will have a huge negative impact on the development of cruise market.

\subsection{Travel agencies}

The travel agency must strengthen the propaganda of cruise tourism activities. At present cruise tourism in China has just started; the cruise lines are not familiar with Chinese consumers, the lack of awareness of cruise ship culture. Travel agency is an important way of promoting the tourists on the cruise, is also the Chinese tourists understand cruise cultural sources of information; the travel agency in the development of cruise tourism has an irreplaceable role. Travel propaganda role, therefore, to understand tourists cruise, enhance the awareness of cruise has an irreplaceable.

Meanwhile, the travel agency should coordinate the relationship between the cruise companies and travel agencies. 
Now China does not have its own cruise company, is the international cruise company management in China, and China's culture is different, some even have some conflict. China has not own Cruise Company, never really belong to our own fleet. The current lines are international cruise, mainly according to the western etiquette and culture design, is not very suitable for the Chinese culture and consumption characteristics.

It is necessary to contact the elderly community. After retirement, the elderly will take part in elderly community. Some of the old clubs enrich their elderly life. It can be said that the elderly community is an important place for old people to obtain information. So, company can strengthen the relationship with elderly community, to strengthen the awareness of cruise tourism.

\subsection{The government}

At present Shanghai Baoshan district established the cruise tourism experimental area, it provides a good opportunity for the development of cruise tourism in shanghai. In order to adapt to the development of cruise tourism spring, Baoshan government should draw lessons from the successful experience of other test area, perfect the infrastructure construction of cruise tourism experimental area, and give full play to the function of the cruise home port.

Perfect cruise regulations formulated. As we all known "nothing can be accomplished without norms or standards", the current policies and laws about cruise is not perfect enough, formulate relevant lines economic development policy and cruise tourism management local rules and regulations, will greatly ensure the cruise also healthy and stable development. According to the consumption characteristics of the elder, government should formulate relevant preferential policies. Such as star cruises company now to launch in the Chinese market, with the old man over 55 of visitors, the elderly can enjoy half-discount. The old man's physical strength weaker than young people, so we can build a special channel for older to reduce unnecessary energy consumption.

Strengthen the training of specialists in the field of the cruise. Universities and colleges in our country has already set up a professional tourism management, but in terms of new type of cruise tourism, also rarely involved. Today staff working on cruise tourism has few aspects of professional knowledge about cruise. People are the key to development. Strengthen the cultivation of talents, pay attention to the importance of internship experience in the cruise is necessary to the development of cruise tourism in shanghai.

\section{Acknowledgements}

This work was financially supported by Scientific Research \& Innovation Project under Shanghai Municipal Educational Committee (13KY0318) and Scientific Research Innovation Program of Shanghai University of Engineering Science.

\section{References}

Adriatic K, Agiomirgianakis G. (2010). Cruise visitors' experience in a Mediterranean port of call, International Journal of Tourism Research, 2010,12.

China statistical yearbook. (2012).

Choir H C, Juppe M, Elliot S. Segmenting Ocean Cruise Ship Tourists.

Hobson J P. (1993). Analysis of the US cruise line industry, Tourism Management, 1993.

Hobson J P. (1993). Analysis of the US cruise line industry, Tourism Management, 1993.

Jackson R. (2004). Beyond the tourist bubble? Cruise ship passengers inport. Annals of Tourism Research, 2004, 31. http://dx.doi.org/10.1016/j.annals.2003.08.003

Jianhai Wu. business in China, (in Chinese).

Mustard G, Morrison A, Cai L,O'Leary J T, Nadkarni N. (1996). Tourist perspectives on cruising: Multidimensional scaling analysis of cruising and holiday types, Journal of Tourism Studies, 1996,7.

Patrick J F, Li X, Park S Y. (2007). Cruise passengers' decision-making processes. Journal of Travel \& Tourism Marketing, 2007, 23. http://dx.doi.org/10.1300/J073v23n01_01

Patrick J F. (2004). Are loyal visitors desired visitors, Tourism Management. http://dx.doi.org/10.1016/S0261-5177(03)00116-X

Patrick J F. (2005). Segmenting cruise passengers with price sensitivity, Tourism Management, 2005, 26.

Teye V, Paris C M. (2011). Cruise line industry and Caribbean tourism: Guest' motivations, activities and destination preference. Tourism Review International, 2011,14.

Yanqing Zhang. Min Kou. Travel journal, (in Chinese.) 